Part of Journal of Research of the National Bureau of Standards, Volume 15, October 1935

\title{
A STUDY FOR THE PREPARATION OF A SPECIFICATION FOR HIGH-EARLY-STRENGTH PORTLAND CEMENT
}

\author{
By G. Rupert Gause
}

ABSTRACT

This paper reports test results to be used as a basis for the preparation of a Federal specification for high-early-strength cement. Samples of 28 commercial cements were investigated. The cements represented a wide spread in compound composition, fineness, and physical properties.

Four plastic mortars were studied. Both the tensile and compressive strength (2-inch cubes) of each of these mortars varied with the different cements over a considerable range. The rate of setting of these cements was measured by the penetration of $300-\mathrm{g}$ needles, one $1 \mathrm{~mm}$ in diameter and one $2 \mathrm{~mm}$ in diameter, into the mortars contained in a Vicat ring.

Measurements of length changes were made on 6 -inch prisms 1 inch square cured under four different conditions.

The requirements for a specification for high-early-strength cement are discussed and recommendations made for tests to be incorporated into such a specification.

\section{CONTENTS}

Page

I. Introduction

II. Materials and storage conditions _........

III. Description of tests.

IV. Results of tests

V. Specification requirements

VI. Summary

\section{INTRODUCTION}

The present study of high-early-strength portland cement was undertaken to obtain data from which a Federal specification could be prepared. Shortly prior to the starting of this work the American Society for Testing Materials had issued a proposed tentative method of test for compressive strength of portland-cement mortar. This method, since adopted as Tentative Method C $109-34 \mathrm{~T},{ }^{1}$ requires a 2-inch test cube made from a plastic mortar of fixed proportions. It was decided to include in the present investigation studies on this particular plastic mortar, together with other mortars of different proportions, as well as tests for compliance with the Tentative Specifications for High-Early-Strength Portland Cement (C 74-30) of the American Society for Testing Materials. ${ }^{2}$

1 Proc. Am. Soc. Testing Materials 34 part I, p. 743 (1934).

2 Proc. Am. Soc. Testing Materials 30 part I, p. 1,016 (1930). 


\section{MATERIALS AND STORAGE CONDITIONS}

Samples of 28 commercial high-early-strength cements in approximately 25-pound lots were obtained from manufacturers, whose cooperation is hereby gratefully acknowledged. Those few cements which were not received in airtight containers were placed in such containers shortly after their arrival. Before testing, each cement was put through a no. 20 sieve to remove any lumps or foreign matter.

Both standard Ottawa sand, meeting the requirements of Federal Specification SS-C-191, and a graded Ottawa sand were used in the tests. The graded sand had the following sizing: 99 percent retained on the no. 100 sieve, 70 percent on the no. 50,1 percent on the no. 30 and none on the no. 16.

Tap water at $21 \pm 2^{\circ} \mathrm{C}$ was used for mixing. The temperature of all dry materials at time of mixing was $21 \pm 2^{\circ} \mathrm{C}$. The air of the laboratory for mixing, molding, and air storage was maintained at a temperature of $21 \pm 2^{\circ} \mathrm{C}$ and at a relative humidity of $60 \pm 5$ percent, and the air of the moist cabinet at the same temperature, but at a relative humidity of 95 percent or higher. The storage tanks contained water at $21 \pm 3^{\circ} \mathrm{C}$.

\section{DESCRIPTION OF TESTS}

A chemical analysis was made of each cement, and the specific surface and distribution of particle size, using the Wagner turbidimeter, were determined.

Tests were made for compliance with the requirements of Federal Specification for Portland Cement, SS-C-191, with tensile strength tests made at 1 and 3 days in addition to the required 7 - and 28-day tests. However, the no. 200 sieve fineness was determined by a wet method. A $10-\mathrm{g}$ sample was placed in a certified no. 200 fullheight sieve, the sample thoroughly wetted by slowly pouring water into the sieve, and then washed for 1 minute by holding sieve and sample under a spray nozzle. The nozzle contained seventeen 0.02 -inch holes and the water was maintained at a nozzle pressure of $15 \mathrm{lb} / \mathrm{in}^{2}$ The sieve with residue was then placed for a period of 15 minutes in an electric oven maintained at 105 to $110^{\circ} \mathrm{C}$. The sieve was then removed from the oven, allowed to cool, and the residue weighed.

Four plastic mortars were studied:

Mortar A was proportioned 1 part of cement to 2.75 parts by weight of graded Ottawa sand, and had a C/W (cement/water, by weight) ratio of 2.0. The proportion of cement and sand was almost exactly as specified by the American Society for Testing Materials in its tentative method $\mathrm{C}$ 109-34T, but the $\mathrm{C} / \mathrm{W}$ ratio was slightly larger.

Mortar B was proportioned the same as mortar A, and the water content adjusted, as shown in table 3, to give a flow of 100 to 110 on the 10-inch flow table.

Mortar $\mathrm{C}$ had a $\mathrm{C} / \mathrm{W}$ ratio of 2.0 , the sand content being adjusted, as shown in table 3 , to give each mortar such a consistency that it had a flow of 100 to 110 . This flow was the same as for mortar B and the $\mathrm{C} / \mathrm{W}$ ratio the same as for mortar $\mathrm{A}$.

Mortar D was proportioned 1 part of cement to 2.77 parts by weight of graded Ottawa sand, and had a $\mathrm{C} / \mathrm{W}$ ratio of 1.88 . These 
are the proportions required by ASTM Tentative Method C109-34T.

On each of the mortars A, B, and C the following tests were made:

1. Strength tests for both tension and compression (2-inch cubes) were made at $1,3,7$, and 28 days.

In addition, on mortar $\mathrm{D}$, strength tests for tension and compression at 1 and 3 days were made on those cements of which sufficient material was available.

2. Immediately after mixing, a mortar was placed in a Vicat ring resting on a glass plate, the top troweled level, and the specimen placed under a $100-\mathrm{g}$ Vicat plunger $10 \mathrm{~mm}$ in diameter, which was brought into contact with the top of the mortar and released exactly 45 seconds after completion of the mixing. The depth of penetration of the plunger in 30 seconds was a measure of consistency.

3. The depth of penetration of a standard $(1 \mathrm{~mm})$ Vicat needle weighing $300 \mathrm{~g}$ and also of a $2-\mathrm{mm}$ needle of the same weight was determined, as a measure of time of set at half-hour intervals until less than $1-\mathrm{mm}$ penetration was obtained. The specimens were made in duplicate.

4a. Two pats 3 inches in diameter by $\frac{1}{2}$ inch in height were formed from each mortar on glass plates and cured in the moist cabinet for 24 hours, then in steam at $98^{\circ}$ to $100^{\circ} \mathrm{C}$ for 5 hours, and observed for signs of shrinkage, disintegration, or warping. One pat was then stored in water at $21^{\circ} \mathrm{C}$ and one in laboratory air, and each was examined at the age of 7,14 , and 28 days.

$4 \mathrm{~b}$. The length changes of 1 - by 1 - by 6 -inch prisms were measured after they had been cured for 24 hours in the moist cabinet and then cured under one of the following four conditions:

1. Five hours in steam at $98^{\circ}$ to $100^{\circ} \mathrm{C}$, then cooled to $21^{\circ}$, and then stored in air at $21^{\circ}$ and readings made at 7,14 , and 28 days.

2. Five hours in steam, then cooled to $21^{\circ} \mathrm{C}$, and then stored in water, and readings made at 7,14 , and 28 days.

3 . Stored in air, and readings made at 7,14 , and 28 days.

4. One hour in saturated steam at $100 \mathrm{lb} /$ in. $^{2}$ gage pressure, then cooled.

The mixing of all plastic mortars, as called for by the proposed method, was done in a vitreous enamel ware bowl of about 1-gallon capacity. The bowl was wiped with a damp cloth, the water poured into it, then the cement was added and mixed with the water for 30 seconds with one hand, then approximately one-half of the sand was added and the mixing continued for another 30 seconds. The remainder of the sand was then added and the mixing continued for 90 seconds. As soon as the mixing was completed the flow-table mold, which had previously been wiped dry and clean, was half filled and puddled, then filled to the rim and puddled, and the surface scraped off with a trowel. The mold was removed and the table given 25 one-half inch drops in 15 seconds. The flow was the increase in the diameter of the mortar expressed as a percentage of the original diameter. 
Briquet and cube molds were greased with a thin film of light cup grease, then placed on a plane brass plate similarly greased and the contacts sealed with a molten mixture of 5 parts of rosin to 3 parts of paraffin, by weight. In molding the briquets and cubes the molds were half filled and puddled with the finger tips, then filled and the puddling repeated. The excess mortar was then scraped off and the tops troweled just enough to secure a smooth surface flush with the top of the mold. Immediately after molding, the specimens were placed in the moist cabinet. They were removed from the molds 23 to 24 hours after making. Those for later ages were placed in water immediately upon their removal from the molds and kept there until tested. The briquets were all tested with the same tensile machine of 1,000-pound capacity. The cubes of cements 1 to 8 were tested with a screw-type machine and the others with a hydraulic machine. Cubes tested with the hydraulic machine were loaded at the rate of 3,000 pounds per square inch per minute.

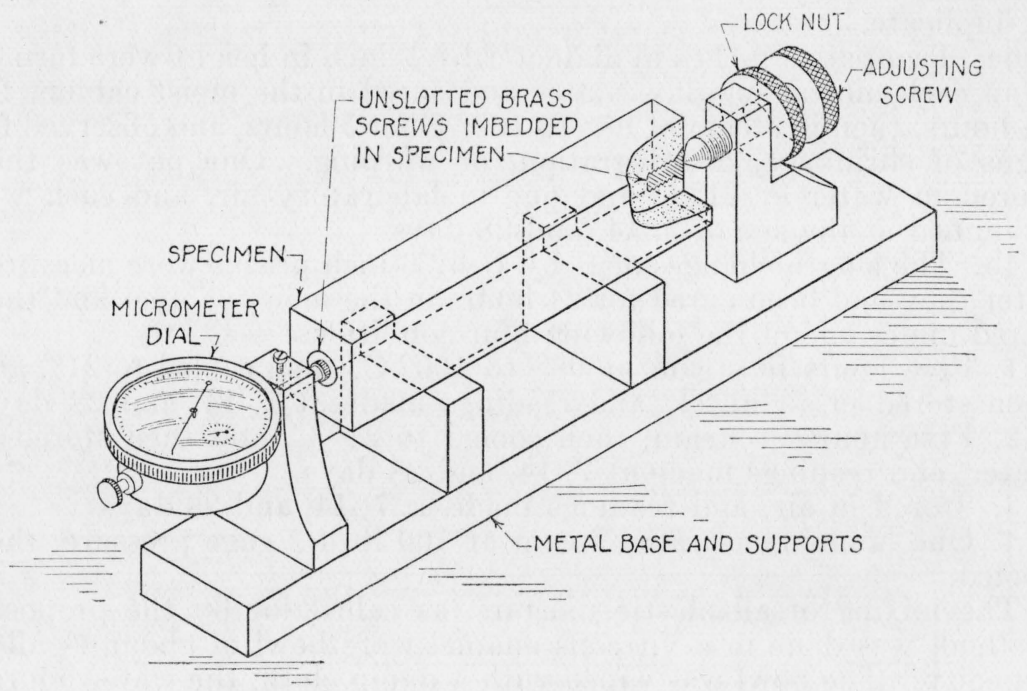

FIGURE 1.-Apparatus for measuring the length of prisms.

The prisms were molded with a special flathead brass screw $1 / 2$ by $3 / 16$ inch in each end. The unslotted screw heads served as reference planes for the length measurements. The molds were filled in the same manner as the cube molds, care being taken to fill completely the ends of the molds around the screws. Immediately after molding, the specimens were placed in the moist cabinet and at the end of 24 hours removed from the molds. The length of each prism was then measured to the nearest 0.0001 inch with the apparatus shown in figure 1 . Two readings were made on each specimen, reversing the prism for the second reading. Four sets of 3 prisms were made from each mortar and cured as described above. 
$\mathrm{T}_{\mathrm{ABLE}}$ 1.-Oxide analysis, compound composition and particle size

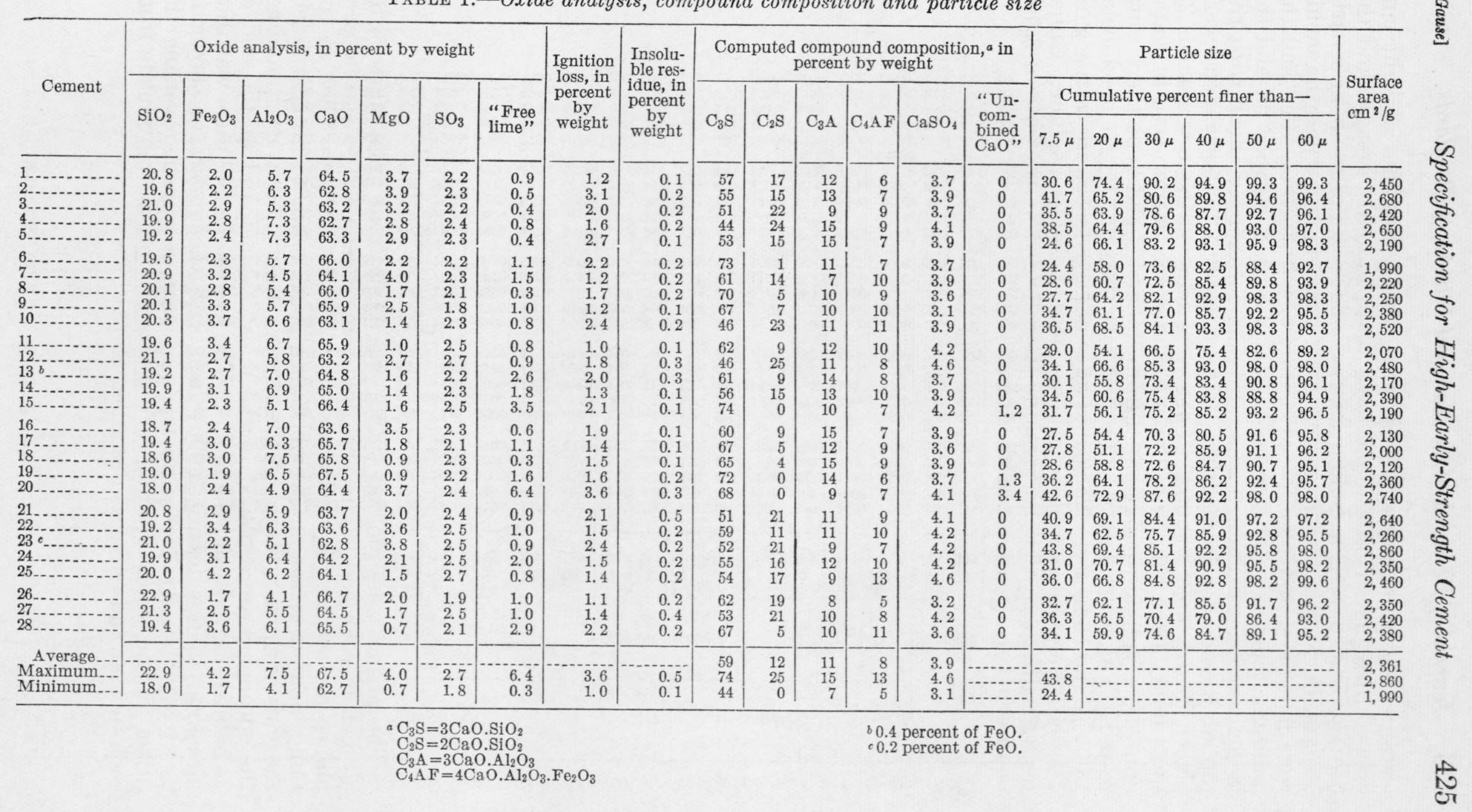


TABLE 2.-Mortar strengths (pounds per square inch)

\begin{tabular}{|c|c|c|c|c|c|c|c|c|c|c|c|c|c|c|c|c|c|c|c|c|c|c|c|c|c|c|c|c|c|c|c|c|}
\hline \multirow{3}{*}{ Cement } & \multicolumn{4}{|c|}{$\begin{array}{l}\text { 1:3 Standard } \\
\text { Ottawa sand } \\
\text { mortar }^{a}\end{array}$} & \multicolumn{8}{|c|}{ Mortar $\mathrm{A}^{b}$} & \multicolumn{8}{|c|}{ Mortar B $b$} & \multicolumn{8}{|c|}{ Mortar $\mathrm{C}^{b}$} & \multicolumn{4}{|c|}{ Mortar $\mathrm{D}^{b}$} \\
\hline & \multicolumn{4}{|c|}{ Tensile strength } & \multicolumn{4}{|c|}{ Tensile strength } & \multicolumn{4}{|c|}{$\begin{array}{l}\text { Compressive } \\
\text { strength }\end{array}$} & \multicolumn{4}{|c|}{ Tensile strength } & \multicolumn{4}{|c|}{$\begin{array}{l}\text { Compressive } \\
\text { strength }\end{array}$} & \multicolumn{4}{|c|}{ Tensile strength } & \multicolumn{4}{|c|}{$\begin{array}{l}\text { Compressive } \\
\text { strength }\end{array}$} & \multicolumn{2}{|c|}{$\begin{array}{l}\text { Tensile } \\
\text { strength }\end{array}$} & \multicolumn{2}{|c|}{$\begin{array}{l}\text { Compres- } \\
\text { sive } \\
\text { strength }\end{array}$} \\
\hline & $\begin{array}{c}1 \\
\text { day }\end{array}$ & $\begin{array}{c}3 \\
\text { day }\end{array}$ & $\begin{array}{c}7 \\
\text { day }\end{array}$ & $\begin{array}{c}28 \\
\text { day }\end{array}$ & $\begin{array}{c}1 \\
\text { day }\end{array}$ & $\begin{array}{c}3 \\
\text { day }\end{array}$ & $\begin{array}{c}7 \\
\text { day }\end{array}$ & $\left|\begin{array}{c}28 \\
\text { day }\end{array}\right|$ & $\begin{array}{c}1 \\
\text { day }\end{array}$ & $\stackrel{3}{\text { day }}$ & $\begin{array}{c}7 \\
\text { day }\end{array}$ & $\begin{array}{c}28 \\
\text { day }\end{array}$ & $\begin{array}{c}1 \\
\text { day }\end{array}$ & $\begin{array}{c}3 \\
\text { day }\end{array}$ & $\begin{array}{c}7 \\
\text { day }\end{array}$ & $\begin{array}{c}28 \\
\text { day }\end{array}$ & $\begin{array}{c}1 \\
\text { day }\end{array}$ & $\begin{array}{c}3 \\
\text { day }\end{array}$ & $\begin{array}{c}7 \\
\text { day }\end{array}$ & $\begin{array}{c}28 \\
\text { day }\end{array}$ & $\begin{array}{c}1 \\
\text { day }\end{array}$ & $\begin{array}{c}3 \\
\text { day }\end{array}$ & $\stackrel{7}{\text { day }}$ & $\begin{array}{c}28 \\
\text { day }\end{array}$ & $\begin{array}{c}1 \\
\text { day }\end{array}$ & $\begin{array}{c}3 \\
\text { day }\end{array}$ & $\begin{array}{c}7 \\
\text { day }\end{array}$ & $\begin{array}{c}28 \\
\text { day }\end{array}$ & $\begin{array}{c}1 \\
\text { day }\end{array}$ & $\begin{array}{c}3 \\
\text { day }\end{array}$ & $\begin{array}{c}1 \\
\text { day }\end{array}$ & $\begin{array}{c}3 \\
\text { day }\end{array}$ \\
\hline & 265 & 350 & 420 & 495 & 215 & 335 & 375 & 490 & 1480 & 3120 & 4220 & 5850 & 185 & 300 & 420 & 440 & 1260 & 3000 & 4520 & 5550 & 210 & 330 & 445 & 520 & 1720 & 3220 & 4850 & 5850 & $d 185$ & $d 300$ & ${ }^{d} 1260$ & d $d 3000$ \\
\hline & 280 & 405 & 480 & 495 & 235 & 315 & 420 & 470 & 1780 & 3450 & 4720 & 6050 & 205 & 330 & 420 & 465 & 1510 & 3100 & 4600 & 5850 & 265 & 360 & 470 & 535 & 2140 & 4100 & 5350 & 7150 & & & & \\
\hline & 220 & 365 & 420 & 505 & 190 & 265 & 350 & 500 & 1080 & 3000 & 4600 & 5700 & 165 & 245 & 330 & 485 & 930 & 2950 & 4520 & 5950 & 185 & 350 & 415 & 505 & 1180 & 3250 & 4850 & \begin{tabular}{|l|}
6550 \\
\end{tabular} & 130 & 280 & 1040 & 2600 \\
\hline & 280 & 390 & 435 & 445 & 205 & 335 & 405 & 495 & 1380 & 3020 & 4350 & 5950 & 175 & 330 & 350 & 455 & 940 & 2600 & 4070 & 5800 & 215 & 370 & 460 & \begin{tabular}{|l|}
510 \\
\end{tabular} & 1520 & 3350 & 5250 & 7150 & & & $\mid 1280$ & . \\
\hline & 305 & 410 & 450 & 450 & 205 & 325 & 385 & 440 & 1300 & 3400 & 3950 & 4250 & $|195|$ & 295 & 360 & 445 & 1070 & 2800 & 3700 & 4550 & 210 & 330 & 395 & 450 & 1410 & 4020 & 4720 & 6150 & & & 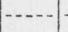 & $\cdots$ \\
\hline & 290 & 390 & 445 & 425 & 220 & 345 & 425 & 505 & 1410 & 3600 & 4870 & 6020 & 160 & 340 & 450 & 525 & 1140 & 3400 & 4920 & 5950 & 220 & 390 & 495 & 530 & 1660 & 4500 & 6300 & 7500 & 170 & 325 & 1380 & 3900 \\
\hline & 295 & 360 & 420 & 500 & 245 & 335 & 370 & 445 & 1820 & 2900 & 3720 & 4950 & 205 & 275 & 355 & 450 & 1220 & 2320 & 3500 & 5070 & 245 & 355 & 450 & 495 & 1770 & 3400 & 4450 & & & & 2010 & ) \\
\hline & 275 & 335 & 380 & 350 & 220 & 330 & 420 & 455 & 1570 & 3020 & 4020 & 4900 & 210 & 310 & 420 & 435 & 1430 & 2800 & 4050 & 5150 & 225 & 355 & 445 & 480 & $|1740|$ & 3420 & 4900 & 5800 & $d 210$ & $d 310$ & d1430 & $d 2800$ \\
\hline & 210 & 350 & 390 & \begin{tabular}{|l|}
455 \\
\end{tabular} & 175 & 290 & 335 & 455 & 1030 & 2350 & 4120 & 5300 & 160 & 275 & 360 & 410 & 970 & 2320 & 3600 & 5250 & $|170|$ & 285 & 405 & 485 & $\mid 1140$ & \begin{tabular}{|l|}
2670 \\
\end{tabular} & \begin{tabular}{|l|}
4470 \\
\end{tabular} & \begin{tabular}{|l|}
6050 \\
\end{tabular} & $d 160$ & $d 275$ & \begin{tabular}{|l|}
$d 970$ \\
\end{tabular} & $d 2320$ \\
\hline & 280 & 390 & 460 & 495 & 205 & 345 & 360 & 460 & 1400 & $|3520|$ & 4650 & 6150 & $\mid 160$ & 310 & 360 & 460 & 1040 & 2870 & 4000 & 5850 & 220 & 395 & 410 & 505 & 1490 & $|3620|$ & 5650 & 7300 & & & & \\
\hline & 265 & 370 & 410 & $500 \mid$ & 185 & 310 & 420 & 445 & 1450 & 2800 & 3870 & 5050 & 170 & 285 & 375 & 405 & 1200 & 2550 & 3650 & 4950 & 205 & 335 & 445 & 495 & 1830 & 3500 & 5150 & & & & & \\
\hline & 280 & 400 & 470 & 460 & 230 & 320 & 420 & 505 & 2060 & 3320 & 4700 & \begin{tabular}{|c|}
6100 \\
\end{tabular} & 200 & 300 & 400 & 495 & 2050 & 2720 & & 5600 & 280 & 360 & 415 & $540 \mid$ & 2260 & 3820 & 5770 & 7000 & & & 1420 & 2750 \\
\hline & 265 & 400 & 455 & \begin{tabular}{|l|}
430 \\
\end{tabular} & 205 & 330 & 405 & 440 & 1710 & 3220 & 4870 & 5800 & 180 & 260 & 370 & 395 & 1220 & 2600 & 4320 & 5150 & 245 & 330 & 410 & 500 & 1700 & \begin{tabular}{|l|}
3800 \\
\end{tabular} & \begin{tabular}{|l|}
5470 \\
\end{tabular} & \begin{tabular}{|l|}
6550 \\
\end{tabular} & 180 & 330 & $\mid 1370$ & 3070 \\
\hline & 305 & 405 & 475 & 460 & 215 & 380 & 410 & 435 & 1660 & 3670 & 5350 & 6250 & 165 & 290 & 390 & 435 & 1170 & 2920 & 4520 & 6100 & 220 & 355 & 425 & 510 & 1700 & 4020 & \begin{tabular}{|l|}
5950 \\
\end{tabular} & 7450 & 215 & 350 & 1300 & 3270 \\
\hline & 285 & 395 & 440 & 425 & 240 & 310 & 445 & 435 & 1970 & 3350 & 4800 & 6000 & 240 & 340 & 415 & 470 & 1560 & 3200 & 5000 & 6000 & 320 & 390 & 555 & 535 & 2290 & 4820 & 6600 & 7950 & 230 & 360 & $|1810|$ & $\begin{array}{l}3200 \\
\end{array}$ \\
\hline & 300 & 365 & 430 & 475 & 200 & 335 & 405 & 465 & 1620 & 3400 & 4570 & 5850 & 155 & 285 & 370 & 425 & 1280 & 2770 & 3800 & 5550 & 240 & 375 & 450 & 500 & 1900 & 3850 & 5550 & 7050 & 200 & 330 & 1330 & 3250 \\
\hline & 280 & 385 & 435 & 460 & 225 & 345 & 415 & 455 & 1820 & 3620 & 482 & 575 & 180 & 31 & 385 & 440 & 1400 & 3120 & & & 260 & 380 & 435 & & 1970 & \begin{tabular}{|l|}
4070 \\
\end{tabular} & & & & & 1630 & \\
\hline & 290 & 395 & 445 & 465 & 240 & 365 & 430 & 495 & 1860 & 4120 & 6300 & 7020 & 195 & 365 & 390 & 445 & 1430 & 3520 & 5150 & 6150 & 280 & 405 & 475 & \begin{tabular}{|l|}
515 \\
\end{tabular} & 2190 & \begin{tabular}{|l|}
4520 \\
\end{tabular} & 6420 & 7600 & 205 & 365 & 1630 & 4050 \\
\hline & 315 & 385 & 415 & 465 & 290 & 355 & 415 & 435 & 2040 & 4370 & 5420 & 5720 & 230 & 345 & 440 & 430 & 1700 & 3700 & 4800 & 5320 & 325 & 405 & 525 & 495 & 2110 & 4800 & 6320 & 7100 & 260 & 380 & 1910 & 3720 \\
\hline & 325 & 385 & 430 & 445 & 245 & 345 & 405 & 465 & 2230 & 3950 & 5100 & 6120 & 190 & 310 & 355 & 460 & 1890 & 3500 & 4650 & 5500 & 245 & 385 & 445 & 480 & 2030 & $\mid 3870$ & 5400 & 6950 & 205 & 315 & 1830 & 3420 \\
\hline & 255 & 290 & 310 & 385 & 180 & 275 & & 390 & 1260 & 2920 & 3720 & 5150 & 150 & 270 & 310 & 400 & 1060 & 2450 & 3600 & 48 & 175 & 320 & 350 & 405 & 1420 & 3270 & 3 & 5 & & & & ... \\
\hline & 305 & 375 & 440 & 470 & 220 & 380 & 425 & 465 & 2020 & 3420 & 4900 & \begin{tabular}{|l|}
6250 \\
\end{tabular} & 185 & 295 & 410 & \begin{tabular}{|l|}
445 \\
\end{tabular} & 1500 & 2820 & 4350 & 5400 & 26 & & 505 & & 2130 & 4170 & 5550 & 7600 & & & & \\
\hline & 255 & 330 & 395 & 415 & 170 & 300 & 375 & 455 & 1210 & 2900 & 4700 & 6150 & 155 & 270 & 340 & 445 & 1010 & 2650 & & & 180 & 30 & 415 & 50 & 1440 & 3400 & & & & & 126 & \\
\hline & 305 & 410 & 475 & 460 & 250 & 340 & 410 & 480 & 1830 & 3670 & 4950 & 6250 & 210 & 310 & 400 & 450 & 1500 & 3350 & 4620 & 6000 & 245 & 380 & 460 & 505 & 1850 & 412 & & 67 & & & $16 t$ & \\
\hline & & 400 & $|475|$ & 525 & 235 & 410 & 425 & 480 & 1400 & 3670 & 200 & 5650 & $|190|$ & | 375 | & 435 & \begin{tabular}{|l|} 
\\
\end{tabular} & 1250 & 3200 & 4620 & 590 & 245 & 40 & 440 & 475 & 1540 & 4220 & 5200 & 6750 & 215 & 390 & | 1480 | & 3620 \\
\hline
\end{tabular}




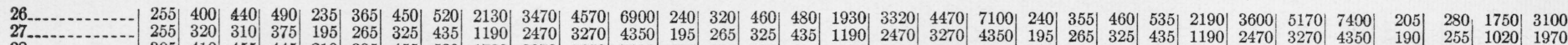

a Mortar of the consistency and proportion required in Federal Specification SS-C-191 for portland cement.

$b$ The proportions by weight of cement and graded Ottawa sand and the C/W ratio, by weight, or the flow of the mortars are as follows:

Mortar A. 1:2.75, C/W

$1: 2.75$, flow

Mortar C. $\{1: \mathrm{X}, \mathrm{C} / \mathrm{W}-\ldots$

Mortar D. $1: 2.77, \mathrm{C} / \mathrm{W}-$

The grading of the sand is as follows:

$$
\begin{gathered}
\text { Amount retained } \\
\text { on sieve no.- }
\end{gathered}
$$

Percent

16

50

- Standard deviation of specimens made from the same batch expressed in percent.

Same specimens for mortars B and D. 


\section{RESULTS OF TESTS}

In table 1 are given the chemical analysis, the compound composition computed by the method as given by Bogue, ${ }^{3}$ the specific surface, and the distribution of particle size for each cement. In calculating the amounts of the compounds the "free $\mathrm{CaO}$ " has been neglected because of the inability to distinguish between $\mathrm{CaO}$, uncombined in the clinker from which the cement was made, and $\mathrm{Ca}(\mathrm{OH})_{2}$ resulting from the hydrolysis of the cement during processing and storage. It is of interest to note that the "free-lime" content of the cements varied up to 6.4 percent. The cements varied through a wide range of composition. One cement had a $\mathrm{C}_{3} \mathrm{~S}$ content of 74 percent and zero $\mathrm{C}_{2} \mathrm{~S}$ content, while at the other extreme was a cement with a $\mathrm{C}_{3} \mathrm{~S}$ content of 46 percent and a $\mathrm{C}_{2} \mathrm{~S}$ content of 25 percent. The $\mathrm{C}_{3} \mathrm{~A}$ content varied from 7 to 15 percent. Two cements exceeded the sulfuric-anhydride limit of 2.5 percent specified in ASTM Tentative Specification C74-30T.

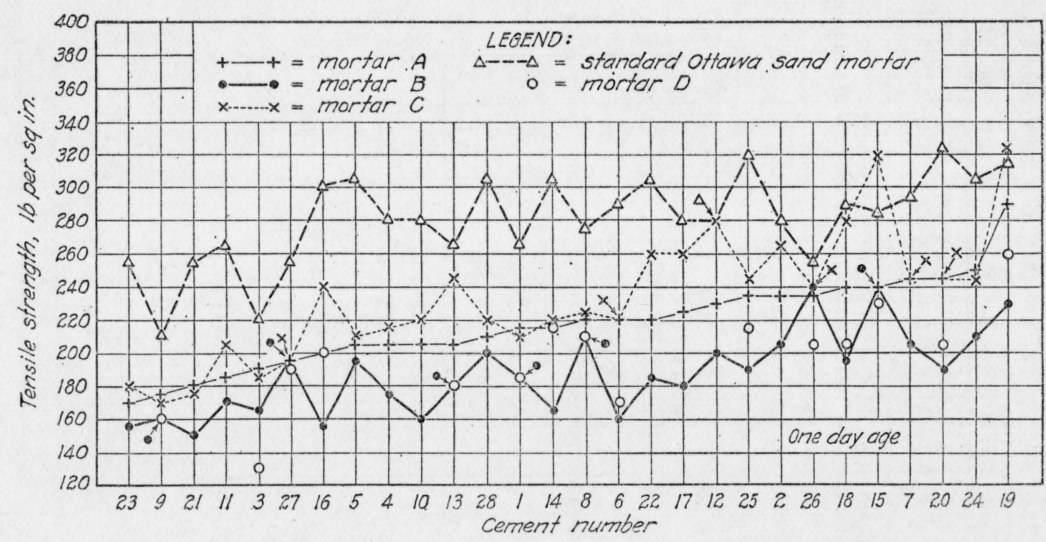

Figure 2.-One-day tensile strengths of plastic-and standard-sand mortars.

The specific surfaces ranged from 1,990 to $2,860 \mathrm{~cm}^{2}$ per g. Normal portland cements have specific surfaces ranging from about 1,400 to $2,000 \mathrm{~cm}^{2}$ per $\mathrm{g}$.

In table 2 are given the results of the strength tests. Each value is the average of tests on 3 specimens made from 1 batch. Nine cements failed to meet the strength requirement of $275 \mathrm{lb} /$ in. $^{2}$ at 1 day and 10 failed to meet that of $375 \mathrm{lb} / \mathrm{in}^{2}{ }^{2}$ at 3 days, as specified in the ASTM tentative specification.

The standard deviations were computed from the formula

$$
\sigma=\sqrt{\frac{\Sigma v^{2}}{2 N}}
$$

where $v=$ deviation of each individual break from the average of three expressed as a percentage of that average, and $N$ is the number of groups of three. These deviations, which give a measure of the uni-

${ }^{3}$ R. H. Bogue, Calculation of Compounds in Portland Cement, Portland Cement Association Fellowship Paper 21. 
formity of tests on specimens made from the same batch, show that the compressive tests were consistently more uniform than the tensile tests. The deviations of the briquet strengths are approximately 50 percent greater than those of the compressive strengths. No one mortar shows a superiority in uniformity over another, nor does there seem to be an appreciable difference between the plastic-mortar briquets and the standard Ottawa sand briquets.

Figure 2 gives the 1-day tensile strengths of each cement for the different mortars, figure 3 the 1-day compressive strengths, figure 4 the 3 -day tensile strengths, and figure 5 the 3 -day compressive strengths. In each case the cements were arbitrarily plotted in the order of the strengths of mortar A. These graphs portray some interesting facts. For most cements the strengths of mortars $\mathrm{C}$ and $\mathrm{B}$ lie respectively, above and below those of mortar A. In general, those cements having high tensile strength have also high compressive strength and those having low tensile strength have also low compressive strength.

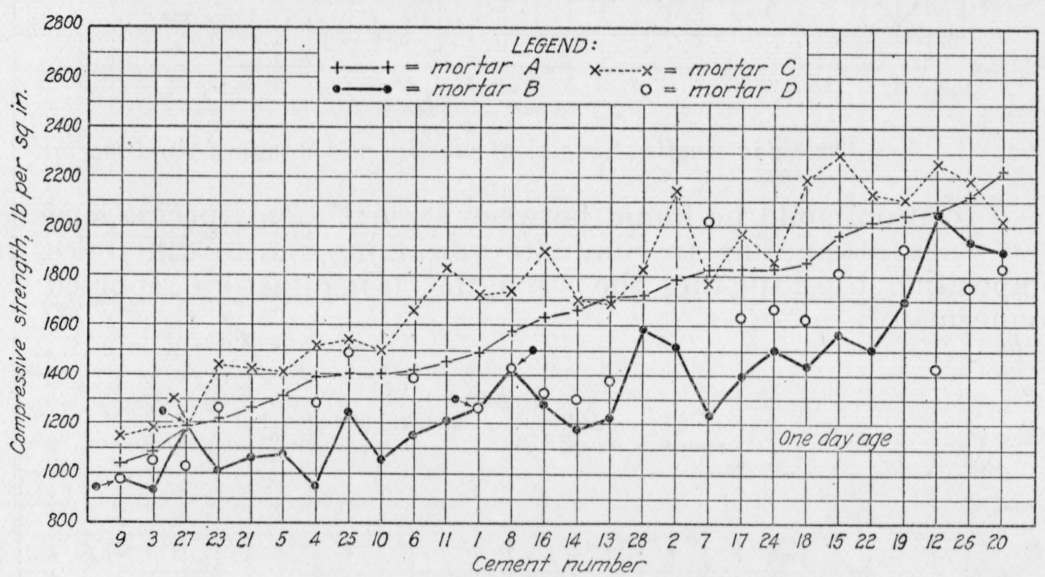

Figure 3.-One-day compressive strengths of plastic mortars.

The strength scales were so chosen that each unit on the compressive scale represents the same percentage of the average compressive strength as each unit on the tensile scale represents in percentage of the tensile strength. The figures show that the compressive strengths rise much more sharply going from left to right than do the tensile strengths. Therefore, the percentage spread in compressive strength for this group of cements is greater than is the percentage snread in tensile strength.

Figures $2,3,4$, and 5 show that decreasing the $\mathrm{C} / \mathrm{W}$ ratio, as in mortar $\mathrm{B}$ relative to mortar $\mathrm{A}$, results in a decrease in strength and that increasing the cement-sand ratio, as in mortar $\mathrm{C}$ relative to mortar A, causes an increase in strength. That is, adjusting the $\mathrm{C} / \mathrm{W}$ ratio and the cement-sand ratio to secure the same flow acts upon the strength in opposite directions.

The average tensile strength of mortar A with respect to age is plotted in figure 6 (a) and the compressive strength in figure 6 (b). The change in strength at 24 hours is about 3.1 percent per hour for tensile and 3.3 percent per hour for compressive, and at 72 hours the change is 0.3 percent per hour for tensile, and 0.5 percent per hour 
for compressive. These percentages are only approximate, but will not vary appreciably for the different mortars or cements. It is evident that 24 -hour tests should be made as near 24 hours as possible and that 72-hour tests should be made within an hour of 72 hours.

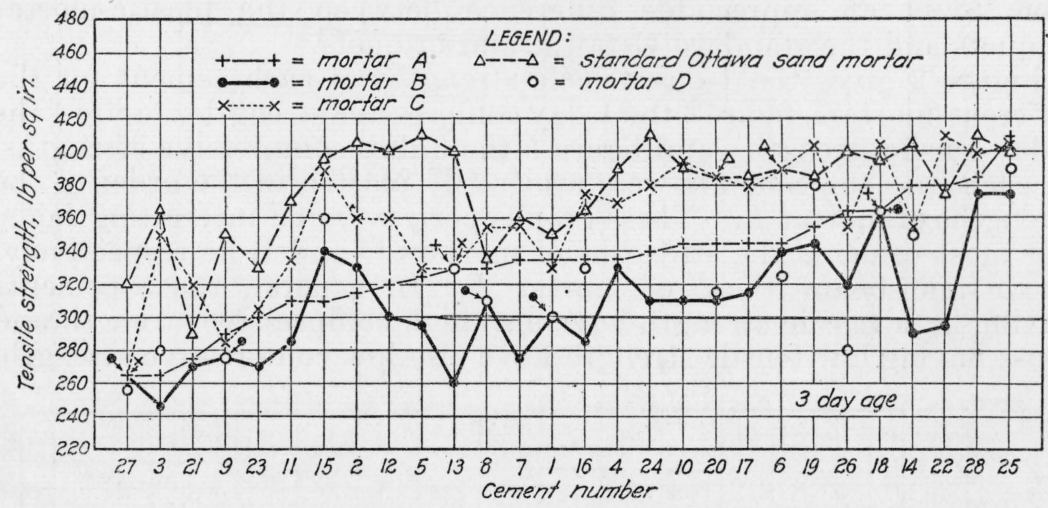

FIGURE 4.-Three-day tensile strengths of plastic- and standard-sand mortars.

No relation could be found between strength and specific surface, even when attempting to eliminate variations due to differences in composition by adjusting the strengths, using factors reported by Gonnerman. ${ }^{4}$

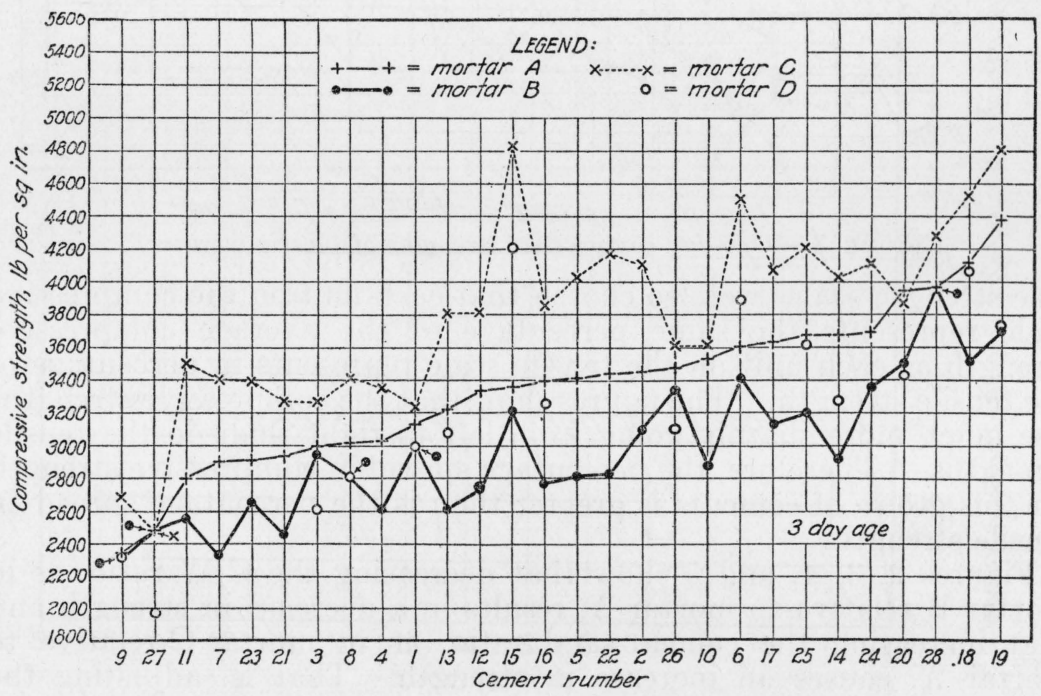

FIGURE 5.-Three-day compressive strengths of plastic mortars.

In table 3 are given the proportions and consistencies of mortars $\mathrm{A}, \mathrm{B}$, and $\mathrm{C}$, as measured by both flow table and $100 \mathrm{-g}$ plunger. The values show that the penetration measurements were much less sensitive than the flow measurements to both changes in $\mathrm{C} / \mathrm{W}$ ratio

\footnotetext{
- Proc. Am. Soc. Testing Materials 34, part II, 287 (1934).
} 
and cement-sand ratio. The table also shows that, with the exception of cements nos. 1 and 25 , the penetrations into mortar $\mathrm{C}$ were greater than those into mortar B, and since these two mortars were
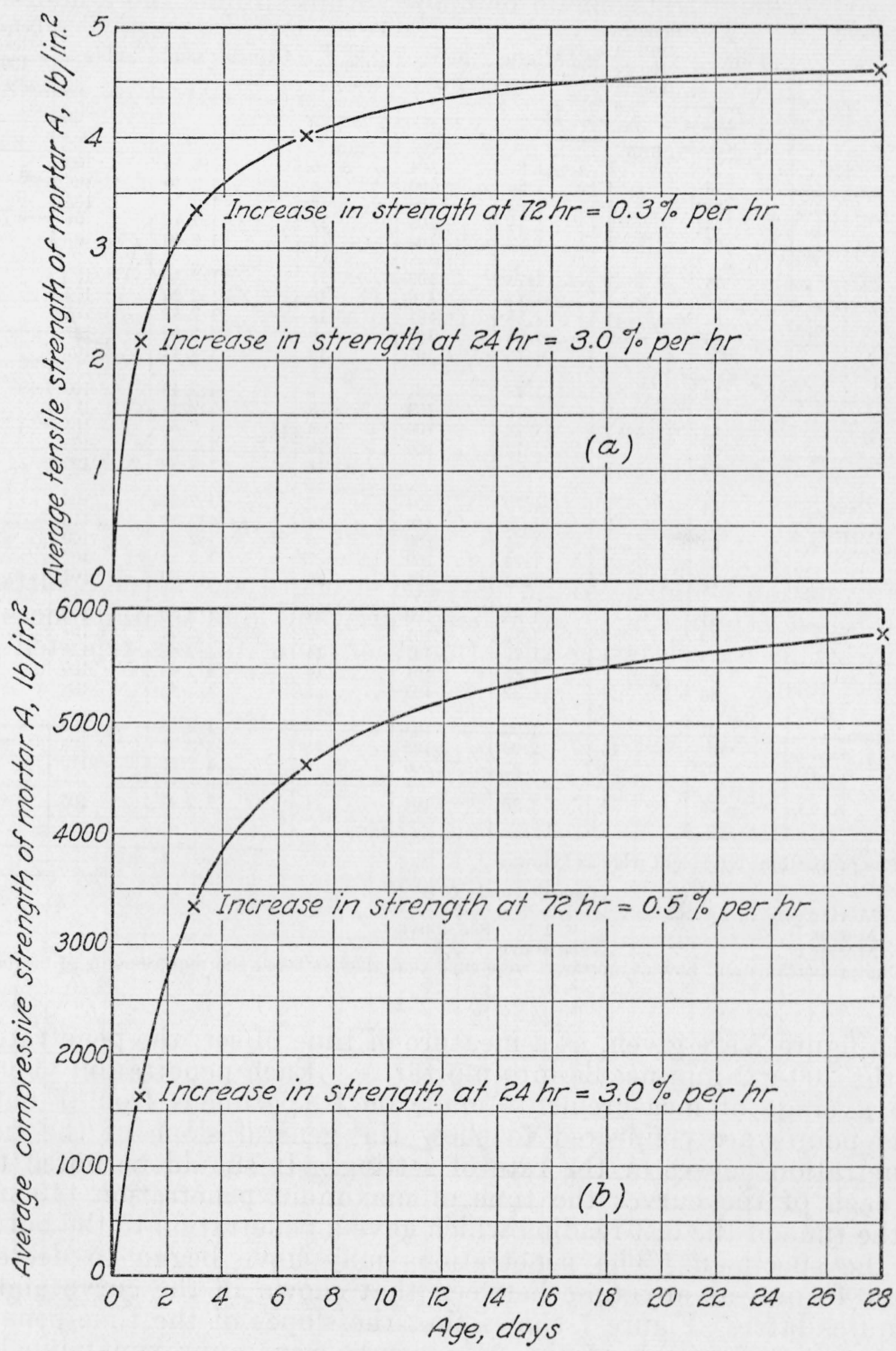

Figure 6.-Relation between strength of plastic mortars and age.

gaged to an approximate common flow, it seems that the penetration measurements are more sensitive to a change in flow produced by varying the cement-sand ratio than they are to the same change in flow produced by varying the $\mathrm{C} / \mathrm{W}$ ratio. 
TABLE 3.-Consistency of Plastic Mortars

\begin{tabular}{|c|c|c|c|c|c|c|c|c|}
\hline \multirow[b]{2}{*}{ Cement } & \multicolumn{2}{|c|}{ Mortar A a } & \multicolumn{3}{|c|}{ Mortar B a } & \multicolumn{3}{|c|}{ Mortar C a } \\
\hline & Flow & $\begin{array}{l}\text { Penetra- } \\
\text { tion of } \\
100-g \\
\text { needle }\end{array}$ & C/W ratio & Flow & $\begin{array}{l}\text { Penetra- } \\
\text { tion of } \\
100 \text {-g } \\
\text { neeule }\end{array}$ & Cement: sand & Flow & $\begin{array}{l}\text { Penetra- } \\
\text { tion of } \\
100-g \\
\text { needle }\end{array}$ \\
\hline $\begin{array}{l}1 \ldots \\
2 \ldots \\
3 \ldots \\
4 \ldots- \\
5 \ldots\end{array}$ & $\begin{array}{l}78 \\
73 \\
88 \\
73 \\
75\end{array}$ & $\begin{array}{r}\mathrm{mm} \\
3 \\
4 \\
5 \\
5 \\
3 \\
4\end{array}$ & $\begin{array}{l}1.87 \\
1.85 \\
1.92 \\
1.78 \\
1.82\end{array}$ & $\begin{array}{l}104 \\
100 \\
100 \\
105 \\
100\end{array}$ & $\begin{array}{r}\mathrm{mm} \\
6 \\
8 \\
12 \\
17 \\
12\end{array}$ & $\begin{array}{l}1: 2.55 \\
1: 2.40 \\
1: 2.55 \\
1: 2.40 \\
1: 2.40\end{array}$ & $\begin{array}{l}100 \\
105 \\
105 \\
104 \\
107\end{array}$ & $\begin{array}{r}\mathrm{mm} \\
5 \\
10 \\
13 \\
18 \\
14\end{array}$ \\
\hline $\begin{array}{r}6 \\
7 \\
8 \\
9 \\
9\end{array}$ & $\begin{array}{l}74 \\
65 \\
81 \\
83 \\
75\end{array}$ & $\begin{array}{r}2 \\
4 \\
11 \\
5 \\
4\end{array}$ & $\begin{array}{l}1.78 \\
1.72 \\
1.88 \\
1.88 \\
1.78\end{array}$ & $\begin{array}{l}109 \\
110 \\
104 \\
100 \\
107\end{array}$ & $\begin{array}{r}11 \\
13 \\
15 \\
9 \\
13\end{array}$ & $\begin{array}{l}1: 2.40 \\
1: 2.30 \\
1: 2.55 \\
1: 2.50 \\
1: 2.42\end{array}$ & $\begin{array}{l}109 \\
108 \\
105 \\
107 \\
107\end{array}$ & $\begin{array}{l}15 \\
33 \\
33 \\
23 \\
17\end{array}$ \\
\hline 11312 & $\begin{array}{l}74 \\
67 \\
65 \\
62 \\
62\end{array}$ & $\begin{array}{l}4 \\
2 \\
2 \\
3 \\
3\end{array}$ & $\begin{array}{l}1.78 \\
1.75 \\
1.75 \\
1.72 \\
1.72\end{array}$ & $\begin{array}{l}101 \\
108 \\
100 \\
106 \\
110\end{array}$ & $\begin{array}{r}7 \\
8 \\
8 \\
10 \\
11\end{array}$ & $\begin{array}{l}1: 2.45 \\
1: 2.35 \\
1: 2.30 \\
1: 2.26 \\
1: 2.30\end{array}$ & $\begin{array}{l}100 \\
104 \\
104 \\
105 \\
109\end{array}$ & $\begin{array}{r}8 \\
14 \\
14 \\
18 \\
20\end{array}$ \\
\hline $\begin{array}{l}16 \\
17 \\
18 \\
19 \\
20\end{array}$ & $\begin{array}{l}64 \\
65 \\
60 \\
62 \\
79\end{array}$ & $\begin{array}{l}2 \\
2 \\
2 \\
2 \\
4\end{array}$ & $\begin{array}{l}1.75 \\
1.75 \\
1.75 \\
1.75 \\
1.85\end{array}$ & $\begin{array}{l}104 \\
110 \\
100 \\
109 \\
104\end{array}$ & $\begin{array}{r}5 \\
14 \\
6 \\
7 \\
25\end{array}$ & $\begin{array}{l}1: 2.26 \\
1: 2.32 \\
1: 2.30 \\
1: 2.32 \\
1: 2.40\end{array}$ & $\begin{array}{l}106 \\
110 \\
100 \\
107 \\
104\end{array}$ & $\begin{array}{l}19 \\
26 \\
10 \\
10 \\
30\end{array}$ \\
\hline $\begin{array}{l}21 \\
22 \\
23 \\
24 \\
25\end{array}$ & $\begin{array}{l}84 \\
59 \\
75 \\
81 \\
80\end{array}$ & $\begin{array}{l}5 \\
3 \\
4 \\
7 \\
3\end{array}$ & $\begin{array}{l}1.85 \\
1.72 \\
1.78 \\
1.85 \\
1.82\end{array}$ & $\begin{array}{l}100 \\
101 \\
101 \\
101 \\
105\end{array}$ & $\begin{array}{r}28 \\
9 \\
14 \\
14 \\
7\end{array}$ & $\begin{array}{l}1: 2.50 \\
1: 2.24 \\
1: 2.42 \\
1: 2.48 \\
1: 2.48\end{array}$ & $\begin{array}{l}100 \\
104 \\
100 \\
109 \\
103\end{array}$ & $\begin{array}{r}30 \\
18 \\
27 \\
19 \\
7\end{array}$ \\
\hline $\begin{array}{l}26-\ldots+\ldots-1 \\
27 \\
28\end{array}$ & $\begin{array}{r}91 \\
105 \\
92\end{array}$ & $\begin{array}{r}5 \\
15 \\
5\end{array}$ & $\begin{array}{l}1.92 \\
2.00 \\
1.92\end{array}$ & $\begin{array}{l}103 \\
105 \\
100\end{array}$ & $\begin{array}{r}7 \\
615 \\
7\end{array}$ & $\begin{array}{l}1: 2.58 \\
1: 2.75 \\
1: 2.56\end{array}$ & $\begin{array}{l}102 \\
105 \\
110\end{array}$ & $\begin{array}{r}10 \\
b 15 \\
9\end{array}$ \\
\hline Avg & 75 & 4 & 1.80 & 104 & 11 & $1: 2.41$ & 105 & 17 \\
\hline
\end{tabular}

a The proportions by weight were as follows:

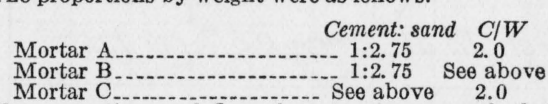

$b$ The proportions and flow of mortar A were such that they satisfied the requirements of mortars B and $\mathrm{C}$.

In figure 7 are given, as a measure of time of set, the penetrations of the $300-\mathrm{g} 2-\mathrm{mm}$ needle into mortar A. Each penetration value is the average of measurements made on 2 specimens from 1 batch. The points are connected to show the general slope of the timepenetration curves or the rate of setting. It should be noted that in each of the curves the time of maximum penetration $(40 \mathrm{~mm})$ is the time of the last reading which gave a penetration to the bottom of the specimen. The penetrations may have begun to decrease from $40 \mathrm{~mm}$ at any time between that shown in the curve and 30 minutes later. Figure 7 shows that the slopes of the time-penetration curves for each of the 28 cements were approximately alike. Figure 8 shows the same similarity of slopes in the time-penetration curves for the $300 \mathrm{~g}$ 1-mm needle. The order of the cements according to the position of their curves in figure 8 is approximately the same as the order according to the position of their curves in figure 7 . We see, therefore, that if we determine a condition of set by a definite penetration, the cements will have about the same relative order of 
time of setting, no matter what particular penetration value we choose or which needle we consider.

Similar data on mortars B and C gave curves of the same form as those in figures 7 and 8 , the only systematic difference being that the penetrations of mortars $\mathrm{B}$ and $\mathrm{C}$ lagged behind those of mortar A by an interval of from 0 to 30 minutes.

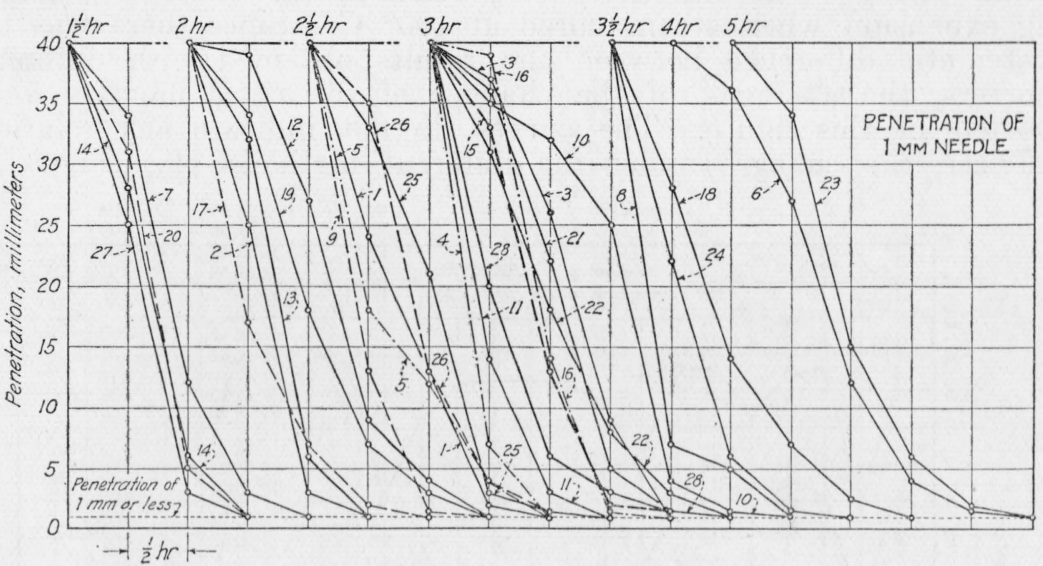

Figure 7.-Time-penetration curves of the 2-mm Vicat needle for different cements.

The precision of these determinations was poor as far as actual penetrations at any time were concerned. That is, at say 4 hours, repeat tests on the same specimens might vary from 10 to $20 \mathrm{~mm}$, and check tests on a duplicate specimen might give results varying from 15 to $25 \mathrm{~mm}$. But the precision with respect to time, at least

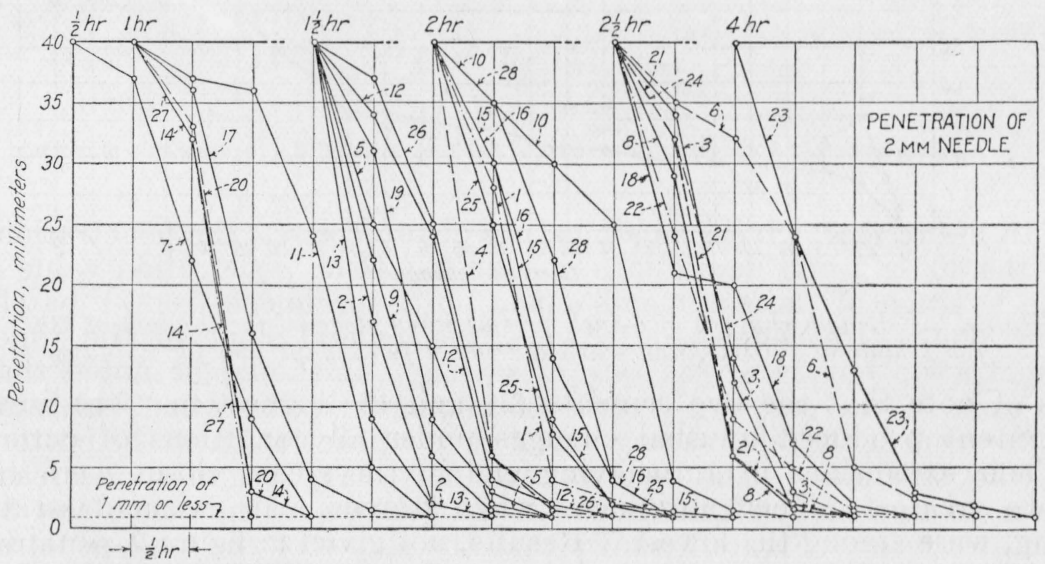

FIGURE 8.-Time-penetration curves of the 1-mm Vicat needle for different cements.

during the initial setting period, was well within a 30 -minute period. That is, on duplicate test specimens the readings of one specimen never lagged behind those of the other by as much as 30 minutes.

In table 4 are given the results of the tests for time of set, fineness, and soundness, when made according to the requirements of the 
Federal specification for portland cement. All cements satisfactorily met the requirements for time of set, soundness, and fineness, of the Federal specification and the ASTM Tentative Specification C $74-30 \mathrm{~T}$.

In figure 9 are shown the length changes of three sets of specimens, the first of which was steam cured at $100^{\circ} \mathrm{C}$ for 5 hours, the second steam cured at $170^{\circ} \mathrm{C}$ for 1 hour, and the third air stored, without steam curing. The cements were plotted in the order of increasing expansion when steam cured at $100^{\circ} \mathrm{C}$. Since there was no systematic difference between the results obtained with different mortars, the averages of the changes of the three mortars were plotted in this figure. The curves do not indicate any relation hetween the changes under the different methods of curing. It

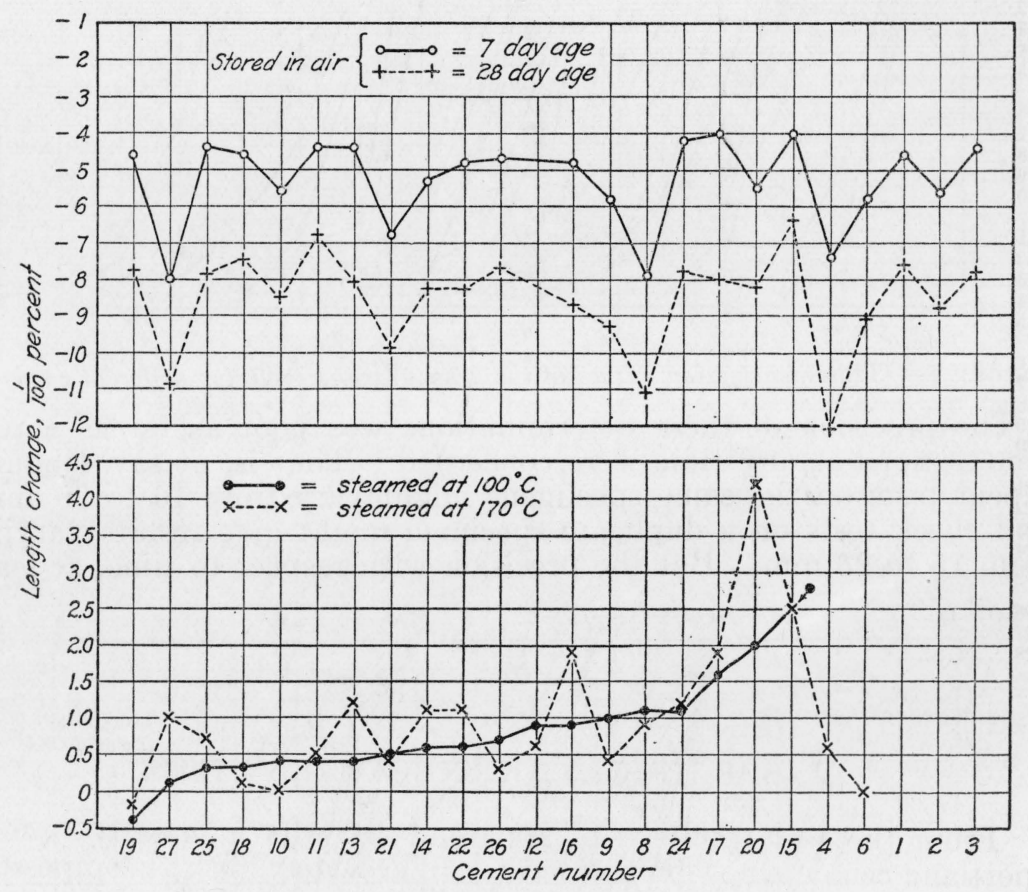

Figure 9.-Length changes of 6 -inch prisms when steamed for 5 hours at $100^{\circ} \mathrm{C}$, for 1 hour at $170^{\circ} \mathrm{C}$, and when air stored for 7 days and for 28 days.

is of note that the two cements (20 and 15) highest in "free-lime" content produced unusual changes under all conditions of curing. Their expansions in autoclaving and in the steam closet were the two greatest. Their shrinkages when stored in air, without steaming, were among the lowest. Results, not given in figure 9, obtained with specimens water stored after steaming at $100^{\circ} \mathrm{C}$, gave at 28 -days age an average expansion for all cements of 1.9 percent, with cements 20 and 15 as extremes with 3.9 and 5.1 percent, respectively. Specimens air stored, after steaming at $100^{\circ} \mathrm{C}$, gave at 28-days age an average contraction of 3.5 percent, with cements 20 and 15 as the two lowest with 1.9 and 0.8 percent, respectively. Although no visual signs of unsoundness were observed in any of the prisms or mortar pats, 
these unusual length changes of the two cements highest in "free lime" cannot but cast a shadow of doubt on the question of their soundness.

TABLE 4.-Fineness, soundness, and time of set

Tests according to methods of Federal Specification for portland cement SS-C-191. The cements were all sound.

\begin{tabular}{|c|c|c|c|c|c|}
\hline \multirow{2}{*}{ Cement } & \multirow{2}{*}{$\begin{array}{l}\mathrm{H}_{2} \mathrm{O} \text { for } \\
\text { norma! } \\
\text { consist- } \\
\text { ency }\end{array}$} & \multicolumn{2}{|c|}{ Time of set } & \multirow{2}{*}{$\begin{array}{l}\text { Residue } \\
\text { on no. } 200 \\
\text { sieve }\end{array}$} & \multirow{2}{*}{ Remarks } \\
\hline & & Initial & Final & & \\
\hline $\begin{array}{l}1 \\
2 \\
3 \\
4 \\
5\end{array}$ & $\begin{array}{l}\%_{28.0} \\
24.4 \\
26.0 \\
25.6 \\
25.6\end{array}$ & $\begin{array}{r}\text { Hours } \\
2^{3} / 4 \\
11 \\
31 / 4 \\
2 \\
21 / 2\end{array}$ & $\begin{array}{r}\text { Hours } \\
51 / 4 \\
31 / 4 \\
43 / 4 \\
4 \\
41 / 4\end{array}$ & $\begin{aligned} & \\
& 0.5 \\
& 1.8 \\
& 1.3 \\
& 1.1 \\
& 0.2\end{aligned}$ & \\
\hline $\begin{array}{r}6 \\
7 \\
8 \\
9 \\
9\end{array}$ & $\begin{array}{l}24.2 \\
26.6 \\
25.6 \\
24.4 \\
25.0\end{array}$ & $\begin{array}{l}23 / 4 \\
2 \\
2^{3} / 4 \\
21 \\
23 \\
23\end{array}$ & $\begin{array}{l}53 / 4 \\
41 / 4 \\
43 / 4 \\
41 / 2 \\
53 / 4\end{array}$ & $\begin{array}{l}2.4 \\
2.4 \\
0.3 \\
1.6 \\
0.7\end{array}$ & $\begin{array}{l}\text { (1). } \\
\text { Waterproofe } 1 . \\
(1) \text {. }\end{array}$ \\
\hline $\begin{array}{l}11 \\
12 \\
13 \\
15\end{array}$ & $\begin{array}{l}24.4 \\
26.8 \\
26.0 \\
25.0 \\
25.0\end{array}$ & $\begin{array}{l}11 / 4 \\
21 / 2 \\
2 \\
11 / 4 \\
21 / 2\end{array}$ & \begin{tabular}{l|}
$43 / 4$ \\
$41 / 4$ \\
$31 / 2$ \\
3 \\
$43 / 4$
\end{tabular} & $\begin{array}{l}4.6 \\
0.5 \\
0.9 \\
1.9 \\
1.0\end{array}$ & $\begin{array}{l}\text { (1). } \\
(1) \text {. }\end{array}$ \\
\hline $\begin{array}{l}16 \\
17 \\
18 \\
19\end{array}$ & $\begin{array}{l}24.8 \\
24.4 \\
25.8 \\
26.0 \\
25.6\end{array}$ & \begin{tabular}{l|}
$21 / 4$ \\
2 \\
$33 / 4$ \\
$21 / 2$ \\
$11 / 4$
\end{tabular} & $\begin{array}{l}41 / 2 \\
31 / 2 \\
6 \\
41 / 2 \\
31 / 4\end{array}$ & $\begin{array}{l}0.9 \\
0.7 \\
1.0 \\
0.9 \\
0.7\end{array}$ & \\
\hline $\begin{array}{l}21 \\
22 \\
23 \\
24 \\
25\end{array}$ & $\begin{array}{l}27.0 \\
24.4 \\
27.0 \\
25.8 \\
26.6\end{array}$ & \begin{tabular}{l|l}
23 & \\
21 & \\
33 & \\
4 & \\
2 &
\end{tabular} & $\begin{array}{l}43 / 4 \\
41 / 2 \\
7 \\
6 \\
4\end{array}$ & $\begin{array}{l}0.8 \\
1.4 \\
0.6 \\
0.2 \\
0.1\end{array}$ & $\begin{array}{l}\text { Waterproofed. } \\
\text { Waterproofed. }\end{array}$ \\
\hline $\begin{array}{l}26 \\
27 \\
28\end{array}$ & $\begin{array}{l}25.0 \\
25.4 \\
24.0\end{array}$ & $\begin{array}{l}21 / 2 \\
11 / 2 \\
13 / 4\end{array}$ & $\begin{array}{l}43 / 4 \\
31 / 2 \\
33 / 4\end{array}$ & $\begin{array}{l}1.7 \\
1.8 \\
1.6\end{array}$ & \\
\hline
\end{tabular}

1 Stiffened up immediately after mixing.

\section{SPECIFICATION REQUIREMENTS}

From the test results it is apparent that the high-early-strength portland cements now on the market differ widely both in composition and in physical properties. In establishing a specification for the acceptance of these cements, the primary consideration should be early strength, for, as the name implies, this property is the distinguishing characteristic between these cements and standard portland cements. The present investigation has shown that the uniformity of the strength of individual cubes made from the same batch is better than that of briquets.

In selecting the most desirable mortar the foregoing data have little to offer. It does seem that the most satisfactory mortar would be one whose $\mathrm{C} / \mathrm{W}$ ratio was determined by some measure of consistency. But the difficulties of such a measure are well known. From other investigations there does not seem to be satisfactory agreement between flow-table measurements made by different laboratories. The Vicat needle, which appears from this investigation to be less sensitive than the flow table, has also the disadvantage of poor pre- 
cision among repeat tests on identical specimens. It seems that until some satisfactory method can be found for determining the $\mathrm{C} / \mathrm{W}$ ratio, the best selection of a mortar would be one of fixed proportions and $\mathrm{C} / \mathrm{W}$ ratio, such as mortar $\mathrm{A}$ or mortar D. Mortar $\mathrm{A}$ was, as a rule, too harsh for ease of placement in the molds. The deviations in table 2 do not give any evidence of this, but greater care was necessary in preparing the specimens of mortar A. Mortars $\mathrm{B}$ and $\mathrm{C}$ were, as a rule, too wet. There was a pronounded rise of water to the top of the specimens, in B more so than in C, and particularly in penetration specimens, which had to be removed from the cabinet every 30 minutes. Mortar $\mathrm{D}$, which has a $\mathrm{C} / \mathrm{W}$ ratio practically halfway between those of mortars $A$ and $B$, seems to be the most desirable. It is estimated that for the same group of cements mortar D should give flows the average of which would be from 85 to 95 percent; and if the mortar specified be one in which the $\mathrm{C} / \mathrm{W}$ ratio is controlled by flow measurements, this range would be preferable to the 100- to 110-percent range of mortar B. It is regrettable that this investigation did not include compression tests on mortars made from standard sand; for it is now realized that the socalled "graded Ottawa sand" used in this investigation is neither a graded sand nor does it produce, when used in the proportions herein studied, a truly plastic mortar which will hold water.

In specifying the particular strengths to be required it may be borne in mind that the manufacturers often claim that these cements will give, at 1 and 3 days, strengths equivalent to those attained by normal portland cements at 7 and 28 days, respectively. A comparison of the results obtained in this investigation with those obtained by Committee $\mathrm{C}-1$ of the American Society for Testing Materials working on normal portland cements ${ }^{5}$ shows that this claim of the manufacturers is hardly approached. The average compressive strengths of seven normal portland cements in plastic mortar cubes of the proportions of mortar D were $2,745 \mathrm{lb} / \mathrm{in}^{2}$ and $4,655 \mathrm{lb} / \mathrm{in}^{2}$ at 7 and 28 days, respectively. These values are higher, respectively, than even the maximum 1- and 3-day strengths obtained in the present investigation upon mortar A or mortar D. True, the tensile strengths of the above seven normal portland cements were far above those required by the Federal specification for portland cement, but the strengths obtained in this investigation with the standard-sand briquets show that many of the cements do not give 1- and 3-day tensile strengths equivalent to the requirements of the Federal specification for portland cement at 7 and 28 days, respectively. It seems, therefore, that to specify such strength requirements for 1 and 3 days as would be equivalent to the Federal specification requirements for normal portland cements at 7 and 28 days, respectively, would not be demanding nearly so much as manufacturers sometimes claim their product to offer and yet would reject several of the present cements and place others on the border line. If tests for tensile strength are specified, it is suggested that $275 \mathrm{lb} / \mathrm{in}^{2}$ at 1 day and $375 \mathrm{lb} / \mathrm{in}^{2}$ at 3 days with standard Ottawa sand briquets be the requirements; and if compressive tests are specified, it is suggested that the compressive strengths of mortar $\mathrm{D}$ equivalent to the above

\footnotetext{
$s$ Report of working committee on plastic mortar tests for portland cement, Proc. Am. Soc. Testing Materials 21, part I, 322 (1934).
} 
tensile strengths be the requirements. A consideration of figures 2, 3,4 , and 5 shows that approximately $1,300 \mathrm{lb} / \mathrm{in}^{2}$ at 1 day and $3,000 \mathrm{lb} /$ in $^{2}$ at 3 days are the compressive strengths of mortar D equivalent to tensile strengths of $275 \mathrm{lb} /$ in $^{2}$ at 1 day and $375 \mathrm{lb} / \mathrm{in}^{2}$ at 3 days with standard Ottawa sand briquets.

The methods followed in mixing, molding, and testing seemed satisfactory. However, the necessity of sealing the molds to the plates is questionable. This process is quite laborious and would entail considerable cost if required in a routine test. The rate of loading offers another question for economic consideration. A recent investigation at this Bureau has shown that rates of loading up to $12,000 \mathrm{lb} / \mathrm{in}^{2}$ per minute gave results as reliable as those obtained when loading at $4,000 \mathrm{lb} / \mathrm{in}^{2}$ per minute. The standard deviations of individual breaks were found to be practically the same at all rates of loading, and the average strengths obtained at each rate were only slightly different. It is therefore suggested that a rate of loading of from 5,000 to $6,000 \mathrm{lb} /$ in $^{2}$ per minute be specified for the 3 -day tests. For the 1-day tests 3,000 to $5,000 \mathrm{lb} /$ in $^{2}$ per minute would be satisfactory.

The initial setting time of high-early-strength cements is a second important consideration. Early setting often accompanies early strength in these cements; therefore, especial attention should be given to adopting a means of rejecting any cement whose quick setting might present difficulties. The results in table 4 show that 5 of these cements had initial setting times of $1 \frac{1}{2}$ hours or less as determined with the Gillmore needle. Any method which relies on a reading of zero penetration is not sensitive. This can be seen from figures 7 and 8, which are typical of time-penetration curves on cement pastes and mortars. These curves fall off rapidly from maximum penetration and then approach zero penetration very slowly. Consequently, it is difficult to determine the precise time at which the penetration is zero, whereas the time at which the penetration is, say $35 \mathrm{~mm}$, can be determined with a fair degree of precision. From the foregoing data it appears that the $300-\mathrm{g} 2-\mathrm{mm}$ needle is conveniently suited for determining the initial setting time. The $1-\mathrm{mm}$ needle is undesirable because its penetrations do not begin to decrease until around 2 hours. The initial set might be defined as that stage of the mortar when the $2-\mathrm{mm}$ needle will penetrate to $5 \mathrm{~mm}$ from the bottom of the specimen. A requirement that a cement, when incorporated in a mortar of the same proportions as mortar D, shall have an initial setting time of not less than 1 hour, would accept one or two cements in this investigation with a very narrow margin and the others with a wide margin.

Since 24-hour strength tests will be made on high-early-strength cements, it does not seem necessary to specify a final setting time.

Soundness is a third consideration in a specification for any cement. Volume changes which are not large enough to produce unsoundness in steaming at $100^{\circ} \mathrm{C}$. may be undesirable, particularly in large-mass construction, and it would be advantageous to include in an acceptance specification a test upon which could be set a limit for these changes. The data obtained in this work offer little upon which to base such a specification. Until more can be learned concerning the volume changes of cement and methods for their measurement, it does not seem advisable to incorporate into a specification a test for 
soundness other than the current one of steaming a pat of neat cement.

In considering a fineness requirement for these cements it is obvious that the percentage retained on a no. 200 sieve means nothing. Moreover, the customary dry method of sieving is not practicable in these cements because of the clogging. It is becoming the practice to include specific-surface requirements in cement specifications. Although the specific surface of these cements does not seem to bear any constant relation to their variations in strength, it is practically certain that much of their superiority in strength over normal portland cements is due to their finer grinding. The highest strengths were obtained with many of the cements of lowest specific surface; therefore, a requirement that the specific surface be greater than $1,900 \mathrm{~cm}^{2} / \mathrm{g}$ would be satisfactory.

The chemical analyses of these cements showed that two cements exceeded the $\mathrm{SO}_{3}$ content of 2.5 percent allowed in the ASTM tentative specification. In this investigation these two cements did not give evidence of any undesirable properties. Having produced no data to show otherwise, the contents of $\mathrm{SO}_{3}, \mathrm{MgO}$, and insoluble, and the loss on ignition allowed in the ASTM tentative specification seem to be satisfactory. Until some method can be developed for determining $\mathrm{CaO}$ distinct from $\mathrm{Ca}(\mathrm{OH})_{2}$ it does not seem advisable to set a limit to the "free-lime" content.

\section{SUMMARY}

1. The 28 commercial high-early-strength portland cements studied differed widely in compound composition and physical properties.

2. The calculated $\mathrm{C}_{3} \mathrm{~S}$ contents of the cements varied from 44 to 74 percent, the $\mathrm{C}_{2} \mathrm{~S}$ contents from 0 to 25 percent, and the $\mathrm{C}_{3} \mathrm{~A}$ contents from 7 to 15 percent. Two cements had $\mathrm{SO}_{3}$ contents exceeding 2.5 percent.

3. The specific surfaces ranged from 1,990 to $2,860 \mathrm{~cm}^{2} / \mathrm{g}$.

4. Nine cements failed to meet the strength requirements of the ASTM Tentative Specification C $74-30 \mathrm{~T}$ of $275 \mathrm{lb} / \mathrm{in}^{2}$ at 1 day, and 10 that of $375 \mathrm{lb} / \mathrm{in} .^{2}$ at 3 days.

5. Four plastic mortars made with graded Ottawa sand were studied. Mortar A had a cement:sand ratio of $1: 2.75$ and a $\mathrm{C} / \mathrm{W}$ ratio of 2.0 by weight. Mortar $B$ had a cement: sand ratio of $1: 2.75$ and a water content adjusted to give a mortar flow of 100 to 110 percent. Mortar $\mathrm{C}$ had a $\mathrm{C} / \mathrm{W}$ ratio of 2.0 and a sand content adjusted to give a flow of 100 to 110 percent. Mortar D had a cement:sand ratio of $1: 2.77$ and a $\mathrm{C} / \mathrm{W}$ ratio of 1.88 .

6. The flows of mortar A ranged from 59 to 105 percent. The $\mathrm{C} / \mathrm{W}$ ratio of mortar $\mathrm{B}$ ranged from 1.72 to 2.00 . The cement:sand proportions of mortar $\mathrm{C}$ ranged from $1: 2.24$ to $1: 2.75$.

7. The tensile strengths of mortar $A$ ranged at 1 day from 170 to $290 \mathrm{lb} /$ in. $^{2}$, at 3 days from 265 to $410 \mathrm{lb} / \mathrm{in}^{2}$, at 7 days from 320 to $455 \mathrm{lb} /$ in. $^{2}$ and at 28 days from 390 to $420 \mathrm{lb} /$ in. $^{2}$ The compressive strengths of mortar A ranged at 1 day from 1,030 to 2,230 lb/in. ${ }^{2}$, at 3 days from 2,350 to $4,370 \mathrm{lb} / \mathrm{in}^{2}{ }^{2}$, at 7 days from 3,270 to 6,300 $\mathrm{lb} / \mathrm{in}^{2}$, and at 28 days from 4,250 to $7,100 \mathrm{lb} / \mathrm{in}^{2}{ }^{2}$ The strengths of mortars $C$ and $B$, as a rule, were respectively somewhat above and below those of mortar $\mathrm{A}$. 
8. The rate of setting was measured by the penetrations of $300-\mathrm{g}$ needles, one $1 \mathrm{~mm}$ and one $2 \mathrm{~mm}$ in diameter, into the mortars contained in a Vicat ring. The 2-mm needle has been suggested as the more suitable of the two needles.

9. Six-inch prisms 1 inch square, after an initial period of 24 hours in a moist cabinet, were measured for length change under four conditions of curing. It is of note that unusual changes were obtained with the two cements having the highest "free-lime" contents.

10. The requirements for a specification for a high-early-strength cement have been discussed, and recommendations made for tests to be incorporated into such a specification.

The author expresses his appreciation to $\mathrm{P}$. H. Bates, who outlined the investigation and directed the work, to J. Tucker, Jr., who assisted in both securing and analyzing the data, and to E. P. Flint, who made the chemical analyses.

Washington, August 29, 1935. 